\title{
IMPROVEMENT OF BEARING CAPACITY OF SQUARE FOOTING ON COMPACTED POND ASH WITH REINFORCEMENT
}

\author{
Ravichandra Honnalli ${ }^{1}$, P.G.Rakaraddi ${ }^{2}$ \\ ${ }^{1}$ Post graduate student, Geotechnical engineering, Department of civil engineering, Basaveshwar engineering college, \\ Bagalkot, Karnataka, India. \\ ${ }^{2}$ Professor, Department of civil engineering, Basaveshwar engineering college, Bagalkot, Karnataka, India.
}

\begin{abstract}
Pond ash is waste by product which is producing in huge quantity by thermal power plants. The disposal of pond ash is the major problem to the environment. The way for disposing pond ash would be as a structural fill for low lying areas and used as embankment material. In this paper laboratory investigations are carried out to improve the bearing capacity of pond ash reinforced with geo-grid by conducting load tests in a model tank. The parameters varied during the tests were number of reinforcement layers and overlapping of reinforcement. The improvement of ultimate bearing capacity is observed. The ultimate bearing capacity ratios were evaluated.
\end{abstract}

Keywords: Pond ash, Geogrid, Square footing, $u / B, h / B, b / B$, Bearing capacity ratio

\section{INTRODUCTION}

Pond ash is the waste product which is producing in huge quantity over the last few decades from the thermal power plants. Disposing of this is a major problem. So in review of this problem the pond ash is used as alternative material to fulfil the specifications. The bearing capacity of pond ash is low so for improving the bearing capacity of pond ash the geosynthetic reinforcements are inclused in pond ash bed.

The present study investigates bearing capacity of square footing on compacted pond ash reinforced with geogrid, by vaying the number of layers of reinforcement $(\mathrm{N})$ as $\mathrm{N}=1,2$ and 3 and overlapping of three Geogrids one above the other.Load settlement curve and the Bearing capacity ratio is used to compare the performance of reinforced and unreinforced pond ash.

\section{LITERATURE}

Many studies have been done on bearing capacity of shallow foundation on reinforced soils by many researchers by changing the foundation material and reinforcements.

Bera et al. (2007)[2] reported about compaction characteristics of pond ash, bearing capacity of square footing on pond ash reinforced with jute geotextile has been published in elsewhere by Ghosh et al.(2005)[5]. Bera et al. (2007) explained about the behavior of footing on pond ash. Jakka et al. (2010)[6] studied on the strength and other geotechnical characteristics of pond ash. Rakesh Datta and Dr Sujit Kumar Pal (2013)[14] studied the bearing capacity of pond ash reinforced with geotextile.

\section{MATERIALS AND METHODOLOGY}

\subsection{Pond Ash}

Pond ash has been collected from the Thermal Power Plant Shaktinagar Raichur India. This is generally grey in colour and pozolanic in nature. The most common chemical compositions of pond ash are $\mathrm{SiO}_{2}, \mathrm{Al}_{2} \mathrm{O}_{3}, \mathrm{MgO}, \mathrm{CaO}$, $\mathrm{Fe} 2 \mathrm{O}_{3}$, organic carbons and other Properties of pond ash are given in Table 1.

Table 1 Properties of Pond ash

\begin{tabular}{|l|l|}
\hline Properties Properties & Results \\
\hline Specific gravity & 2.048 \\
\hline Grain size & \\
Gravel & $38 \%$ \\
Coarse sand & $3.85 \%$ \\
Med sand & $21.45 \%$ \\
Fine sand & $52.36 \%$ \\
Fines (silt\&clay) & $21.85 \%$ \\
\hline Liquid limit & $55 \%$ \\
\hline Plastic limit & $\mathrm{NP}$ \\
\hline MDD(kN/m $\left.{ }^{3}\right)$ & 11.2 \\
\hline $\begin{array}{l}\text { Optimum Moisture Content } \\
(\%)\end{array}$ & $31 \%$ \\
\hline CBR(\%)(soaked) & $10 \%$ \\
\hline Shear Strength Parameters: & 0.31 \\
Cohesion, c (kPa) & $20^{\circ} 21^{\prime}$ \\
Angle of Internal Friction, $\phi$ & \\
(degree) & \\
\hline
\end{tabular}




\subsection{Reinforcement}

Type of geosynthetic namely geo-grid (SG-200) was used as the reinforcement material in the Pond ash bed for the model tests. The Geo-grid (SG-200) was obtained from STRATA GEOSYSTEMS, Mumbai (IND) PVT.LTD. The geogrid is made of polypropylene and is black in colour. The properties of Geo-grid (SG200) are as shown in Table 2.

Table 2 Properties of geo-grid (Supplied by STRATA SG 200)

\begin{tabular}{|l|l|}
\hline Type & SG 200 \\
\hline Tensile Strength $(\mathrm{kN} / \mathrm{m})$ & 52.5 \\
\hline Long term design strength $(\mathrm{kN} / \mathrm{m})$ & 35.09 \\
\hline Grid Size, $(\mathrm{mm})$ & $18.3 \times 16.5$ \\
\hline Thickness $(\mathrm{mm})$ & 2 \\
\hline
\end{tabular}

\subsection{Experimental Arrangement}

The tests were performed in a model tank of length, width, and depth of $75 \mathrm{~cm}, 75 \mathrm{~cm}$ and $45 \mathrm{~cm}$. Sides of the box are stiffened with extra battens. Stored pond ash samples were mixed with predetermined moisture content. The pond ash is poured to the model tank and it is compacted to optimum moisture content and maximum dry density (MDD) by Standard Proctor hammer. The compactions were carried out in layers and densities found out by core cutter method. The geogrid layer was placed in desired depths for different values of $\mathrm{N}$ (number of layers) and overlapping of one over other.

After achieving densities load is applied to model footing by hand operated screw jack supported against reaction frame. The arrangement of the setup is shown in Fig 1.

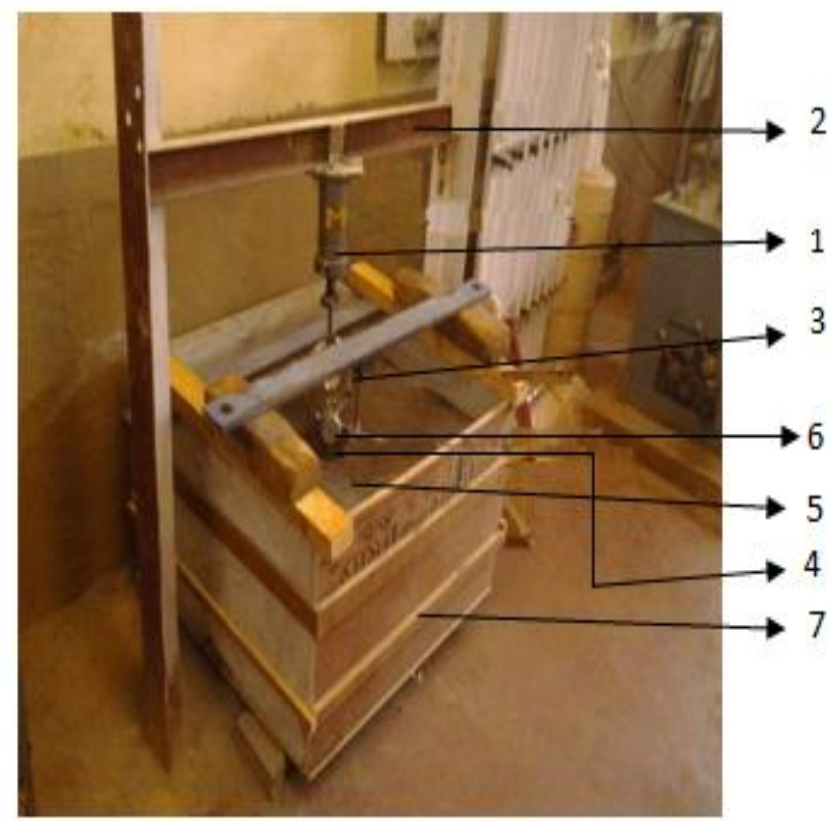

Fig-1: Experimental setup in laboratory 1) Screw jack, 2) Loading frame 3) Proving ring 4) Model footing 5) Pond ash 6) Dial guage 7) Test tank
The layout and configuration of placing of reinforcement layers is as shown in Fig 2

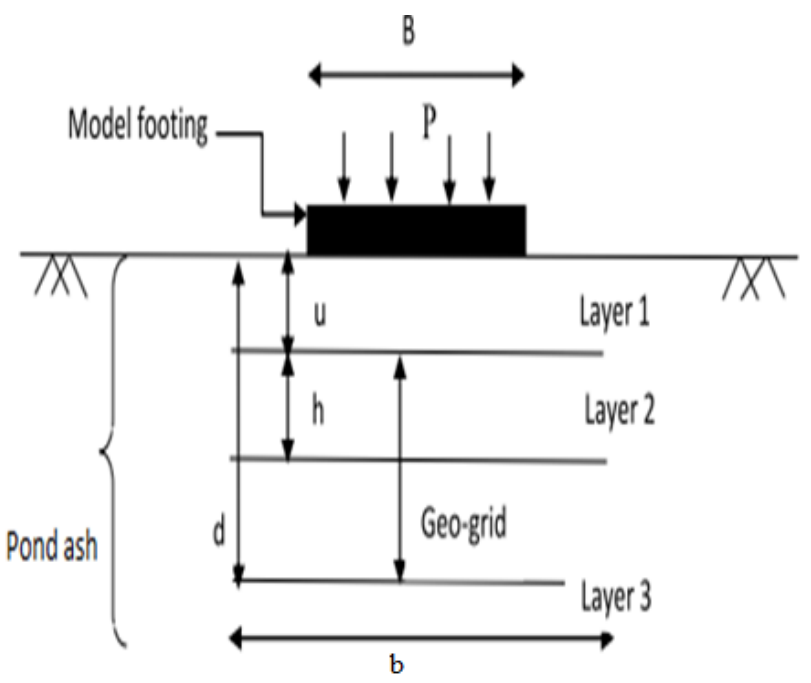

Fig-2: Layout and configuration three dimensional reinforcement layers in the test.

Where $\mathrm{B}=$ Width of model footing.

$\mathrm{P}=$ Vertical load.

$\mathrm{u}=$ Depth of top layer of reinforcement below the model footing.

$\mathrm{h}=$ Vertical spacing between adjacent layers. $b=$ Width of reinforcement layer.

\subsection{Placing of Geogrid}

First the test is done without reinforcement and for the test with reinforcement, the geogrid layer is placed at a depth of 0.4B [10] from the base of footing. Fig 3 shows the placing of geogrid. Since in this test, width of square footing is $12 \mathrm{~cm}$, the depth of first layer for layer 1 is taken as $4.8 . \mathrm{cm}$ from base of the footing and width of reinforcement is $60 \mathrm{~cm}$. For $2^{\text {nd }}$ layer, first layer is at $4.8 \mathrm{~cm}$ and next is at $4.8 \mathrm{~cm}$ from the first layer and for $3^{\text {rd }}$ layer first layer is at $4.8 \mathrm{~cm}$, second and third layers at $4.8 \mathrm{~cm}$ from first layer and second layer.

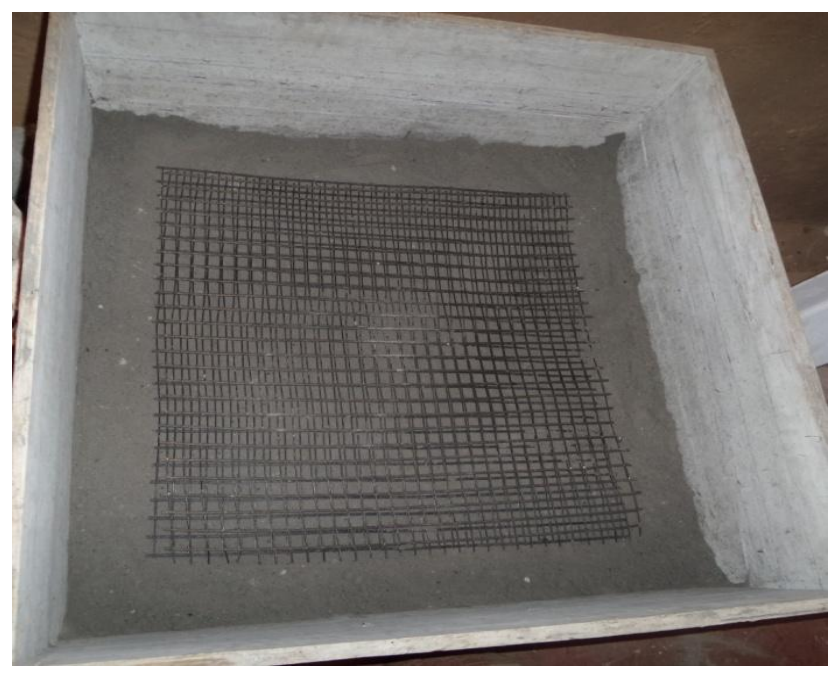

Fig-3: Placing of geogrid 


\section{RESULTS AND DISCUSSIONS}

From the obtained results from laboratory tests following curves are plotted.

\subsection{Bearing Capacity of Unreinforced Pond Ash}

The load carrying capacity of the unreinforced pond ash was carried using square footing. The Figure 4 shows the loadsettlement curve of unreinforced pond ash of a square footing. The ultimate load carrying capacity of the unreinforced pond ash is found to be $3.2 \mathrm{kN}$.

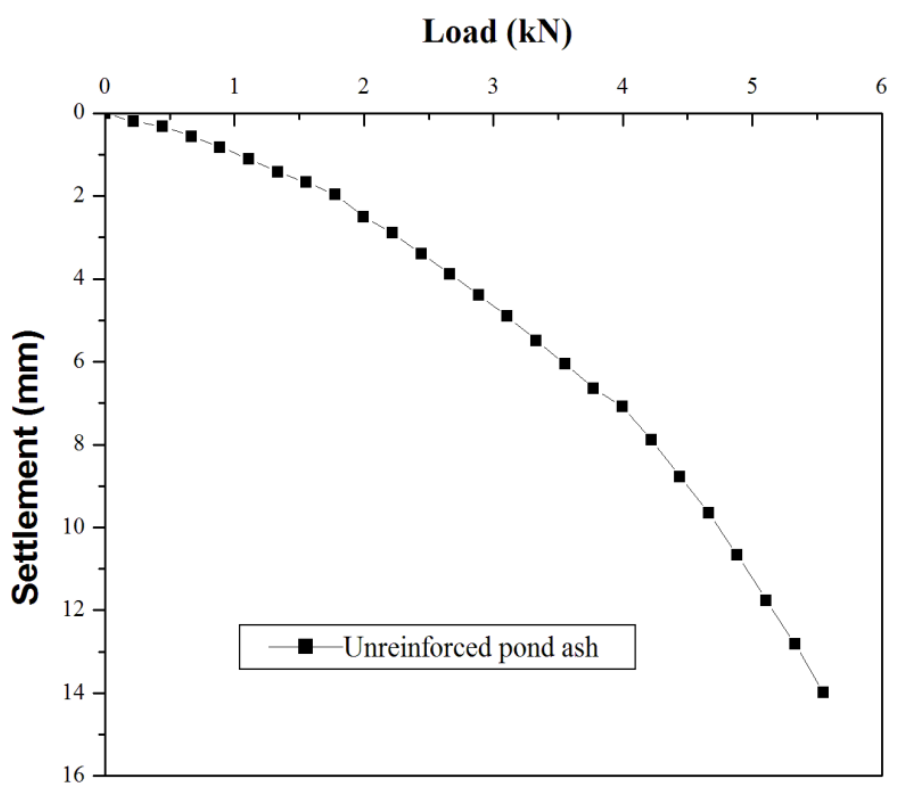

Fig-4: Load settlement curve for the unreinforced pond ash

\subsection{Bearing Capacity of Reinforced Pond Ash by}

\section{Varying the Number of Layers of Geogrid}

Tests were conducted with varying the number of the reinforcement layers $(\mathrm{N})$ by changing the value of $\mathrm{N}$ as 1,2 and 3 by keeping the $\mathrm{u} / \mathrm{B}$ and $\mathrm{h} / \mathrm{B}$ ratio equal to 0.40 and $\mathrm{b} / \mathrm{B}$ ratios as 2 . The Figure 4 shows the load settlement curve for $\mathrm{N}=0,1,2$ and 3 . From Fig-7. the values of ultimate load $\left(\mathrm{q}_{\mathrm{u}}\right)$ were found to be $3.2 \mathrm{kN}, 3.4 \mathrm{kN}, 4.0 \mathrm{kN}$ and $4.4 \mathrm{kN}$ respectively for values of $\mathrm{N}$ equal to $0,1,2$ and 3 for pond ash with SG-200 geogrid reinforcement.

The increase in the layers of the geogrid leads to restrict the movement of soil particles results in increase in load bearing capacity. Hence, it is clear from the graph that the bearing capacity increases with increase in number of layers of geogrid.

Bearing capacity ratio $\left(\mathrm{BCR}_{\mathrm{u}}\right)$ is calculated as the ratio of bearing capacity of reinforced pond ash and of unreinforced pond ash.. The value of bearing capacity ratio $\left(\mathrm{BCR}_{\mathrm{u}}\right)$ increased from 1 to 1.375 as the value of $\mathrm{N}$ value increased from 0 to 3 . With expansion in geogrid layers there is a increase in bearing capacity as shown in Figure 6.

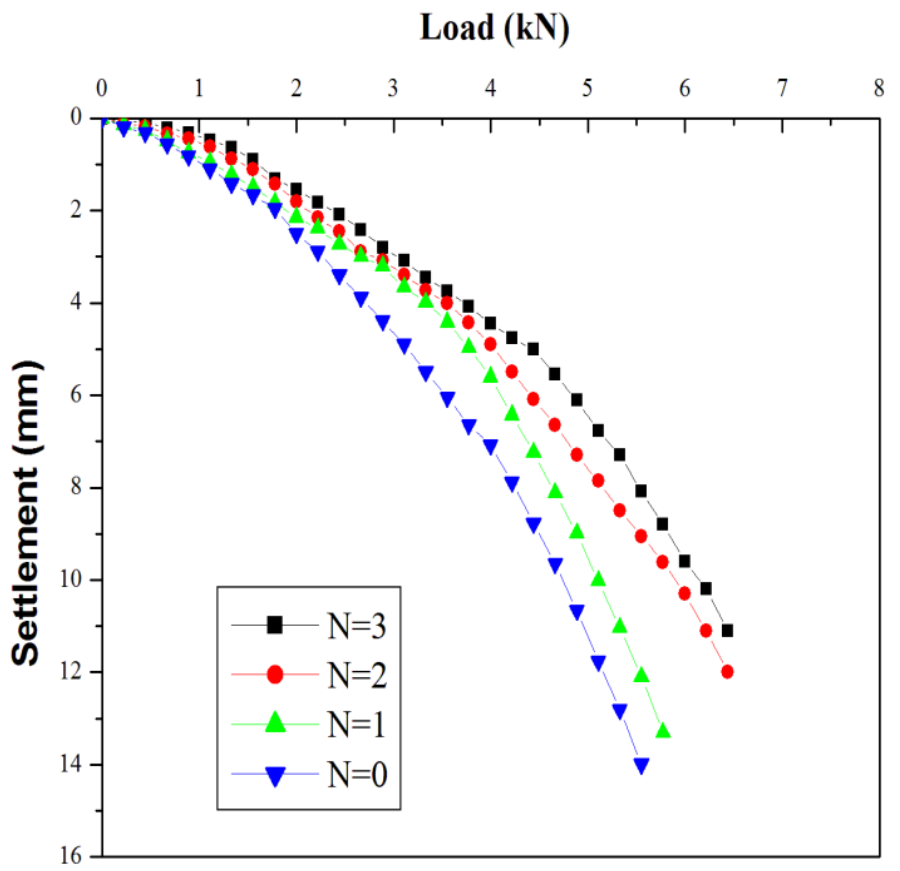

Fig-5: Load settlement curve for reinforced pond ash with variation of geogrid layers

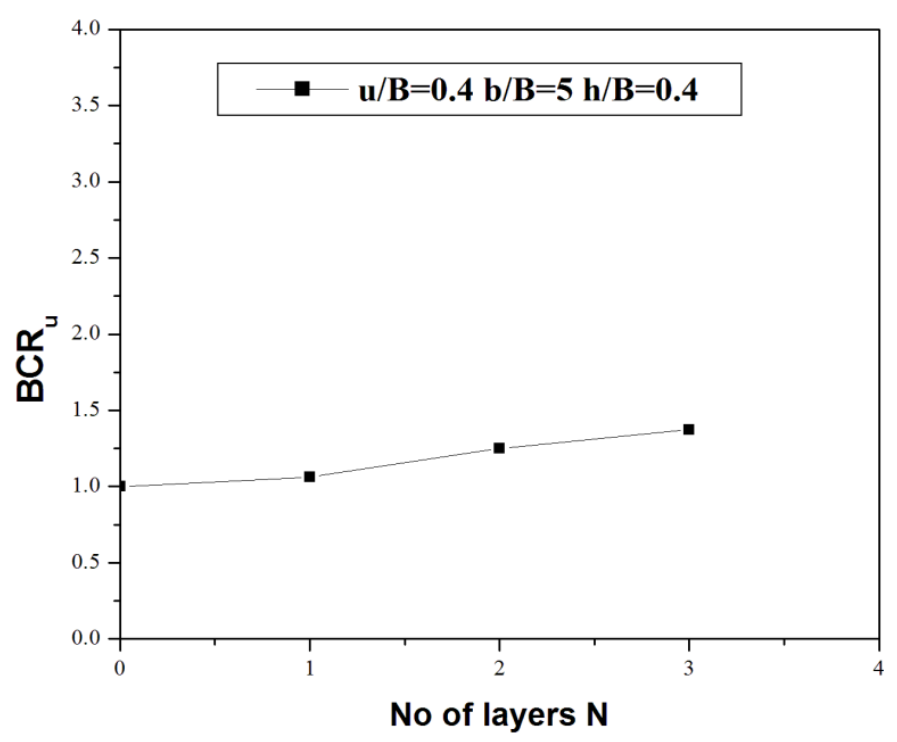

Fig-6: Variation of $\mathrm{BCR}_{\mathrm{u}}$ with number of layers

\subsection{Effect of Overlapping of Three Geogrids with}

\section{Number Layers Constant}

These tests were conducted with the overlapping of three geogrids one above the other while keeping number of layers, $\mathrm{u} / \mathrm{B}$ ratio, $\mathrm{h} / \mathrm{B}$ ratio and $\mathrm{b} / \mathrm{B}$ ratio equal to $3,0.4,0.4$ and 5 respectively. The geogrids are over lapped one over the other in three numbers in different layers and different combinations. The load settlement curve plotted as shown in Fig-7. The ultimate load for overlapping of $1^{\text {st }}, 2^{\text {nd }}$ and $3^{\text {rd }}$ layer is found to be $5.10 \mathrm{kN}, 4.90 \mathrm{kN}$ and $4.80 \mathrm{kN}$ respectively. From the Fig-7 it is observed that $1^{\text {st }}$ layer overlapped with three geogrids will carry the maximum load of $5.10 \mathrm{kN}$. 
Graph of $\mathrm{BCR}_{\mathrm{u}}$ Vs layer number is ploted in Fig 8. The value of ultimate bearing capacity ratio $\left(\mathrm{BCR}_{\mathrm{u}}\right)$ for pond ash reinforced with SG-200 geogrid is observed to be more for the $1^{\text {st }}$ layer overlapped with three geogrids and it decreases for the $2^{\text {nd }}$ layer and $3^{\text {rd }}$ layer overlapped with three geo-grids as shown in Fig 9. The values of ultimate bearing capacity ratios $\left(\mathrm{BCR}_{\mathrm{u}}\right)$ are $1.60,1.53$ and 1.50 for the overlapping of $1^{\text {st }}, 2^{\text {nd }}$ and $3^{\text {rd }}$ layers with three geogrids.

\section{Load (kN)}

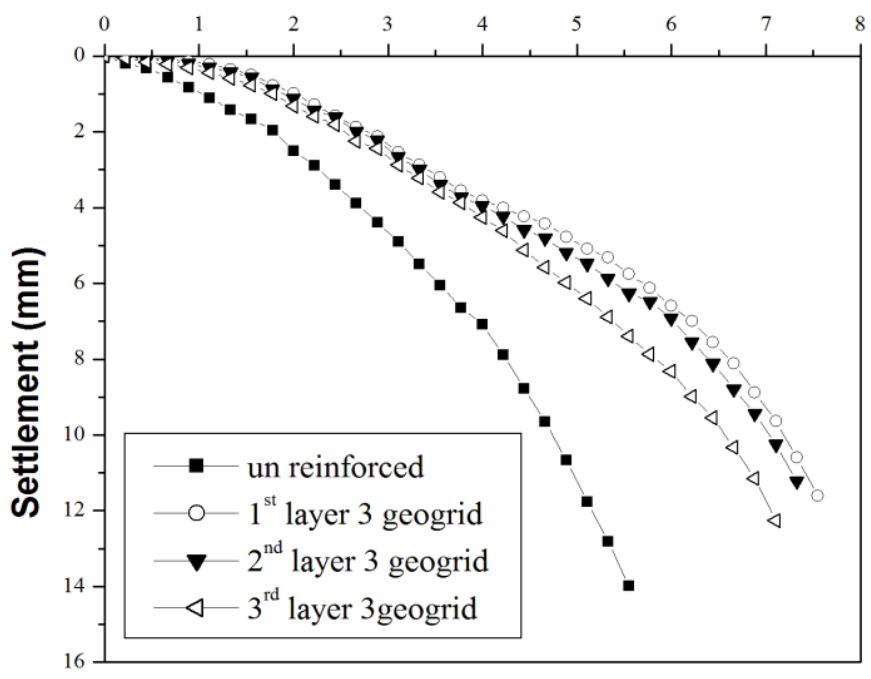

Fig-7: Load vs settlement curve for overlapping of three geo-grids

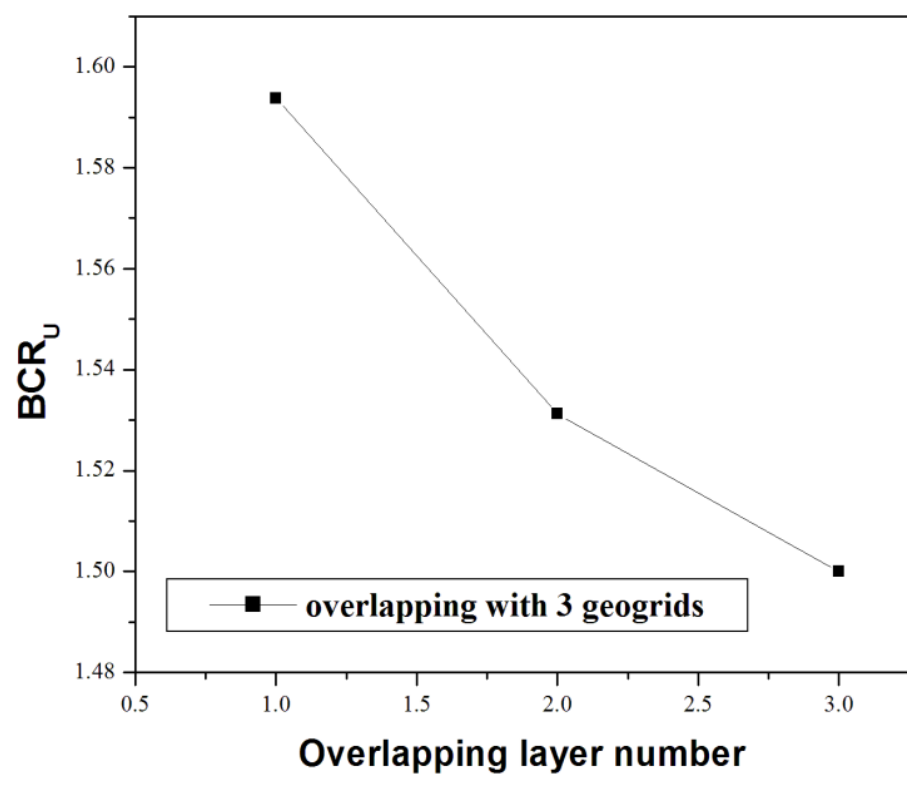

Fig-8: Variation Of $\mathrm{BCR}_{\mathrm{u}}$ with Overlapping with 3 geogrids

\section{CONCLUSION}

From the above graphs it can be concluded that, with utilization of geogrid settlement of the footing can be diminished. As number of layers builds, settlement of the balance diminishes. The procurement of geogrid significantly enhances a definitive load bearing capacity of the model footing at all the levels of settlement considered during the study. As the number of layers of reinforcement increases load bearing capacity increases upto $37 \%$ for $\mathrm{N}=3$ layers.With overlapping of geogrid one over the other the load bearing capacity of square footing on compacted pond ash more for the top layer and less for base layers.

\section{REFERENCES}

[1]. Kumar, R., Kanaujia, V.K. and Chandra, D "Engineering Behaviour of Fibre-Reinforced Pond ash and Silty Sand", Geosynthetics International,Vol.6(6),(1999):pp.509-518

[2]. Bera, A. K., Ghosh, A. and Ghosh , A. "Behaviour of Model Footing on Pond Ash",Goetech Geol Eng,(2007):pp. 315-325

[3]. Goutam Kumar Pothal And Venkatappa Rao G." Behaviour of a Strip Footing on Compacted Pond As Reinforced with Coir Geotextiles" International Journal of Advanced Technology in Civil Engineering(2007) :pp 7-13

[4]. Bera, A. K., Ghosh, A. and Ghosh, A. "Shear Strength Response of Reinforced Pond Ash", Construction and Building Materials, vol.23,(2009):pp. 2386-2393

[5]. Ghosh Ambarish "Compaction Characteristics and Bearing Ratio of Pond ash Stabilized with Lime and Phosphogypsum", Journal of Materials in Civil Engineering @ ASCE, (2010):pp. 343-351

[6]. Jakka, R.S., Ramana, G.V. and Datta, M. "Shear Behaviour of Loose and Compacted Pond Ash". Goetech Geol Eng,Vol.28(6),(2010):pp.763-778

[7]. Arumugam K, Ilangovan R and James Manohar D “ A study on characterization and use of Pond Ash as fineaggregate in Concrete" International Journal Of Civil And Structural Engineering Volume 2, No 2, 2011:pp 466474.

[8]. Sharan A. (2011)" Strength characteristics of fibre reinforced compacted pond ash" M.tech thesis, NIT, Rourkela..

[9]. M.V.S.Sreedhar, G.Venkatappa Rao and R Ramesh Reddy "Bearing Capacity Of Pond Ash Reinforced With A Non-Woven Geotextile" Proceedings of Indian Geotechnical Conference December 15-17,2011, Kochi (Paper No. J169)

[10]. Balendra Mouli Marrapu and Ravi Shankar Jakka "Analysis Of A Road Embankment With Pond Ash In An Active Seismic Region” 15WCEE LISBOA 2012.

[11]. Raju Sarkar, S.M. Abbas and J.T. Shahu "Study Of Geotechnical Behaviour Of Pond Ash Mixed With Marble Dust" International Journal of Advanced Technology in Civil Engineering, ISSN: 2231 -5721, Volume-1, Issue-2, 2012 pp 99-106

[12]. Mohanty S and N. R. Patra (2013) "Liquefaction Behavior Of Panki Pond Ash" Proceedings of Indian Geotechnical Conference December 22-24,2013, Roorkee [13]. Rakesh Datta and Sujit Kumar Pal "Laboratory Investigation on Bearing Capacity Behaviour of Pond Ash Reinforced with Geotextile Grid" EJGE Vol. 18 [2013], Bund. H PP 1631-1639. 


\section{BIOGRAPHIES}

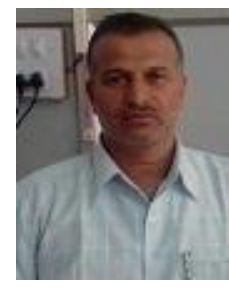

Dr P G Rakaraddi. Presently working as professor in Civil engineering department, Basaveshwar Engineering College Bagalkot 587102, Karnataka. He had post graduate in IIT Kharagpur. And also he got $\mathrm{PhD}$ in Soil Dynamics from IISc Bangalore.

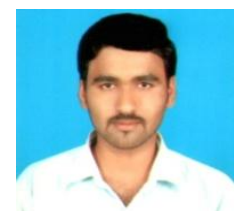

Ravichandra Honnalli, Pursuing Post Graduation in geotechnical engineering at Basaveshwar Engineering College Bagalkot, Karnataka. 